\title{
Use of an Anti-Low Density Lipoprotein Receptor Antibody to Quantify the Role of the LDL Receptor in the Removal of Chylomicron Remnants in the Mouse In Vivo
}

Sungshin Y. Choi, ${ }^{\star}$ Loren G. Fong, ${ }^{*}$ Melissa J. Kirven, ${ }^{*}$ and Allen D. Cooper**

${ }^{*}$ Research Institute, Palo Alto Medical Foundation, Palo Alto, California 94301; and ${ }^{\ddagger}$ Department of Medicine, Stanford University, Stanford, California 94305

\begin{abstract}
Lipoproteins are removed from the plasma by LDL receptordependent and -independent pathways. The relative contribution of these has been established for LDL by using modified lipoproteins, but this has not been possible for apoE-rich lipoproteins, such as chylomicron remnants. To do this, we used a monospecific antibody to the rat LDL receptor. The antibody was injected intravenously into mice followed by ${ }^{125}$ I-lipoproteins. Blood samples were obtained sequentially and radioactivity measured to determine the plasma clearance of the lipoproteins. The animals were then sacrificed and the tissues removed, dried, and the radioactivity measured to determine tissue uptake. An albumin space was also measured to correct for blood trapping. With ${ }^{125}$ I-human LDL, $\sim 50 \%$ of the injected dose was cleared in $180 \mathrm{~min}$. This was reduced to $30 \%$ by the antibody and this was identical to the disappearance of reductively methylated LDL. This is a lower estimate of LDLmediated uptake $(\mathbf{4 0 \%})$ than in other species. LDL uptake per gram tissue was similar for the liver and the adrenal gland and was $\sim 50 \%$ LDL receptor-dependent in both tissues. With ${ }^{125}$ I-chylomicron remnants, clearance was much more rapid with $\sim 50 \%$ cleared in 5 min. By agarose gel electrophoresis, radioactivity was not transferred from chylomicron remnants to other lipoprotein classes. Chylomicron remnants with label on only apoB or in ${ }^{3} \mathrm{H}$-cholesterol esters showed a similar pattern. Combining the estimates of the three labeling procedures, $\sim 35 \%$ of the $30 \mathrm{~s}$ and $25 \%$ of the 5 min chylomicron remnant disappearance was LDL receptor dependent. The liver, per gram tissue, took up five times as much radioactivity as the adrenal gland. At $5 \mathrm{~min}$, at least $50 \%$ of this was LDL receptordependent in liver and $65 \%$ in adrenal gland. We conclude that the LDL receptor plays a major, and somewhat similar quantitative role in the clearance of both LDL and chylomicron remnants in the mouse. However, at least in the mouse, non-LDL receptor-mediated lipoprotein clearance is quantitatively important and is also very rapid for chylomicron remnants. Thus, for chylomicron remnants, it can easily compensate for LDL
\end{abstract}

Address correspondence to Allen D. Cooper, M.D., Research Institute, PAMF, 860 Bryant St., Palo Alto, CA 94301. 1991.

Received for publication 13 March 1991 and in revised form 14 June

1. Abbreviations used in this paper: DLT, dilactitol ${ }^{125} \mathrm{I}$-tyramine; FH, familial hypercholesterolemia; HRP, horseradish peroxidase; LRP, LDL receptor-like protein; RM, reductively methylated.

J. Clin. Invest.

(c) The American Society for Clinical Investigation, Inc.

0021-9738/91/10/1173/09 $\$ 2.00$

Volume 88, October 1991, 1173-1181 receptors if they are blocked or absent. Further, the tissue distribution of lipoprotein uptake may be directed by factors other than LDL receptor density. (J. Clin. Invest. 1991. 88:11731181.) Key words: lipoprotein $\bullet$ LDL receptor • chylomicron remnant • cholesterol $\bullet$ triglyceride $\cdot$ LDL

\section{Introduction}

Because the discovery of a strong positive correlation between plasma LDL and the incidence of coronary heart disease (1), the determinants of the level of LDL in the serum have been studied intensively. The classic studies of Brown and Goldstein identified a receptor on the surface of most cells (2) that initiates the uptake of intact plasma LDL particles into the cell via endocytosis, and thus plays a major role in maintaining cholesterol homeostasis. Although the receptor recognizes both apoB and apoE, it has a much greater affinity for apoE than apoB (3). The number of receptors expressed on the surface of a cell is regulated by the cellular cholesterol content; LDL receptors are downregulated when substantial amounts of cholesterol are delivered to the cells, thus preventing them from accumulating excess cholesterol (4). Quantitatively, the major site of LDL receptor-mediated lipoprotein degradation is the liver. However, even in the complete absence of LDL receptors, a large fraction of LDL continues to be taken up by hepatocytes (5), indicating that there is at least one mechanism other than the LDL receptor that can play a role in the catabolism of LDL. Furthermore, other lipoproteins, including chylomicron remnants, seem to have both LDL receptor-dependent and -independent mechanisms of transport (6).

Chemically-modified forms of LDL, such as reductively methylated LDL (7) and 1,2-cyclohexanedione-modified LDL (8), have been used to determine the relative contribution of LDL receptor-dependent and -independent pathways to LDL metabolism. However, it has been difficult to definitively separate the contributions of LDL receptor and non-LDL receptor-mediated transport for lipoproteins other than LDL. The development of an anti-LDL receptor antibody which specifcally blocks the LDL receptor (9) allowed us to approach this problem. We have observed (10) that the degradation of chylomicron remnants in isolated primary rat hepatocytes in vitro could be almost completely abolished by the addition of the anti-LDL receptor antibody, suggesting that processing of chylomicron remnants by hepatocytes can be dependent upon the LDL receptor. These results are not entirely consistent with observations in Watanabe rabbits (11) and in patients with familial hypercholesterolemia (FH) (12) in which clearance of chylomicron remnants was rapid, although LDL receptors were absent, thus suggesting that either the LDL receptor has a limited role in remnant removal or that an alternate mechanism can compensate for an absence of LDL receptors. The 
recent description (13) of an LDL receptor-related protein (LRP) that can bind lipoproteins that are enriched in apoE (14) and is not subject to down regulation by cholesterol provides a potential mediator of such an alternate pathway.

To directly examine the role of LDL receptor-dependent and -independent pathways to the plasma clearance and tissue uptake of chylomicron remnants in vivo, mice were injected with anti-LDL receptor antibody, and the plasma removal of subsequently injected lipoproteins was measured. The results suggest that the LDL receptor plays a major quantitative role in the clearance and tissue uptake of both LDL and chylomicron remnants in the normal mouse in vivo.

\section{Methods}

Animals. Female Swiss Webster mice, weighing 27-30 g, were purchased from Simonsen Laboratories and housed with a 12-h light cycle (7 am-7 pm) and free access to a standard mouse chow and tap water. Sprague-Dawley-derived rats from the same source were fed a standard diet until they were used as lymph donors.

Reagents. Radioiodine ( ${ }^{125}$ I-carrier-free) was purchased from Amersham Corp., Arlington, IL, and tissue culture media were from Gibco, Grand Island, NY. Fatty acid-poor bovine albumin (BSA) were obtained from Behring Diagnostics, San Diego, CA. All other chemicals were obtained from Sigma Chemical Co., St. Louis, MO, or J. T. Baker Chemical Co., Phillipsburg, NJ.

Preparation of lipoproteins. Human LDL $(d 1.019-1.063 \mathrm{~g} / \mathrm{ml})$ was isolated from EDTA-containing plasma by density gradient ultracentrifugation (15) and radiolabeled with $\mathrm{Na}^{125} \mathrm{I}$ using Iodogen (22). The acetylation and reductive methylation (RM) of LDL were performed as described by Basu et al. (17) and Weisgraber et al. (18), respectively. Dilactitol ${ }^{125}$ I-tyramine (DLT)-LDL was prepared using the method of Strobel et al. (19). Chylomicrons were prepared by the method previously described (20), and chylomicron remnants were prepared by the modification of the method of Redgrave and Martin (21) previously described (22). Chylomicron remnants were radiolabeled using three different procedures. For most of the experiments, isolated chylomicron remnants were iodinated by a modification (22) of the iodine monochloride method (23). In one group of experiments, chylomicron remnants were isolated from rats that had been injected with chylomicrons that had been previously radiolabeled by the iodine monochloride method. In another group of experiments, chylomicron remnants were labeled with ${ }^{3} \mathrm{H}$-cholesterol ester by the method of Fielding (24). All lipoproteins were screened for biologic activity as described below. In addition, the degree of lipid iodination was monitored on all batches as previously described and fell within the range previously reported (22). Selected batches were analyzed by PAGE in a system containing $0.5 \%$ SDS with or without autoradiography, and apoprotein contents and iodination patterns were similar to previously reported values (25). Total protein concentration of lipoproteins was determined by the method of Lowry et al. (26).

Anti-LDL receptor antibodies. The anti-LDL receptor antibodies used have been previously described and characterized $(9,27)$. Monospecificity and lack of cross-reactivity with the LRP have been previously documented (27).

Degradation of lipoproteins by mouse macrophages. Resident mouse peritoneal macrophages were harvested from mice by peritoneal lavage and resuspended in DMEM supplemented with 10\% FCS at a density of $1.25 \times 10^{6}$ peritoneal cells $/ \mathrm{ml}$. $1 \mathrm{ml}$ of the cell suspension was added to 24-well tissue culture plates (Costar, Cambridge, MA) and incubated at $37^{\circ} \mathrm{C}$ for $2 \mathrm{~h}$. Nonadherent cells were removed by rinsing three times with DMEM containing $0.5 \%$ BSA and $10 \mathrm{mM} \mathrm{N}$-2-hydroxyethylpiperazine- $N$ '-2-ethane-sulfonic acid (Hepes) (pH 7.4). The cells were then incubated with ${ }^{125} \mathrm{I}$-labeled lipoproteins $(10 \mu \mathrm{g} / \mathrm{ml})$ in the presence or absence of unlabeled lipoproteins or anti-LDL receptor antibody at $37^{\circ} \mathrm{C}$ for $4 \mathrm{~h}$. The extent of lipoprotein degradation was assessed by measuring the amount of TCA and silver nitrate soluble radioactivity present in the incubation medium. The small amount of degradation products generated in the absence of cells was also measured and subtracted from the corresponding samples incubated with cells.

Disappearance of lipoproteins from plasma. Mice were injected intravenously with $20 \mu \mathrm{g}$ protein of ${ }^{125}$ I-labeled LDL or chylomicron remnants in $0.1 \mathrm{ml}$ PBS via the tail vein. Blood samples were withdrawn at various time points thereafter into heparinized capillary tubes by puncturing the retroorbital plexus (28). Radioactivity in $10 \mu$ l of blood was then measured in a gamma counter. The amount of lipoprotein remaining in the plasma was expressed as a percentage of the calculated initial blood concentration $\left(T_{0}\right)$. The initial plasma concentration was estimated for LDL by extrapolating the amount of lipoprotein at time zero from the first two measured values or, for chylomicron remnants, by calculating the corrected theoretical initial plasma concentration based on the amount injected, the approximate blood volume $(9 \%$ of body weight) and the recovery of injected material as determined in the LDL removal experiments (the difference between the extrapolated initial concentration and the injected dose divided by the blood volume; see Results and Discussion).

Determination of specific tissue spaces. After the last blood sample was collected, the animals were sacrificed and various tissues removed, rinsed in PBS, and dried in an oven. The weight and the amount of radioactivity was then measured. Tissue spaces were calculated by the method of Spady and Dietschy (29) using the following formula: tissue space (microliters plasma per gram dry tissue weight) $=[\mathrm{cpm}$ in tissue/(grams dry weight $\times \mathrm{cpm} / \mathrm{microliters} \mathrm{plasma)].} \mathrm{The} \mathrm{cpm} \mathrm{per}$ microliters plasma was calculated from the average of the amount of radioactivity in the 0 - and 5-min or 0 - and 180-min samples for chylomicron remnants and LDL, respectively. A tissue space for ${ }^{125} \mathrm{I}-\mathrm{BSA}$ was determined to correct for nonspecific trapping of lipoproteins. The albumin space for specific tissue spaces of lipoproteins was then calculated by subtracting the ${ }^{125}$ I-albumin space from the lipoprotein tissue spaces (29). The results were expressed as the microliters of plasma per gram of dry tissue weight. Liver weights in grams were LDL, $0.397 \pm 0.06 ;$ LDL plus antibody, $0.389 \pm 0.032$; remnants, $0.329 \pm 0.04$; remnants plus antibody, $0.345 \pm 0.026$.

Immunoblotting. Membranes from mouse liver and adrenal glands and liver from ethinyl estradiol-treated rats were prepared and solubilized as described earlier (27). The solubilized membranes (200 $\mu \mathrm{g})$ were separated on $6 \%$ polyacrylamide gels by the method of Laemmli (30) under nonreducing conditions. Immunoblotting for the LDL receptor was performed as previously described (9). Briefly, proteins were transferred to nitrocellulose paper by blotting as described, and the portion of the paper containing the molecular weight standards was cut off and stained with $0.1 \%$ amido black. The remainder of the paper was incubated with $1 \mu \mathrm{g} / \mathrm{ml}$ polyclonal anti-rat LDL receptor rabbit antiserum for $1 \mathrm{~h}$ at room temperature, washed, and then incubated with horseradish peroxidase (HRP) conjugated goat anti-rabbit IgG. The HRP conjugated IgG was developed with the Immuno-Blot ${ }^{\mathrm{TM}}$ (GARHRO) assay kit (Bio-Rad Laboratories, Inc., Richmond, CA). The nitrocellulose paper was dried and then scanned with a densitometer (Hoefer Scientific Instruments, San Francisco, CA).

Statistics. Statistical analysis was done by nonpaired Student's $t$ test.

\section{Results}

Characterization of lipoproteins. The lipoproteins used were routinely characterized by assessing their apoprotein compositions and measuring their rate of degradation by mouse macrophages. The apoprotein compositions of LDL, reductively methylated LDL, and chylomicron remnants were analyzed by SDS-PAGE (data not shown). The apoprotein patterns were always comparable to those reported by us and others $(22,25)$. 
To functionally test the lipoproteins, they were incubated with mouse peritoneal macrophages. Specific degradation of both ${ }^{125} \mathrm{I}-\mathrm{LDL}$ and ${ }^{125}$ I-chylomicron remnants could be demonstrated. As previously reported (31), chylomicron remnants were degraded at a slower rate than LDL; however, degradation of both LDL and chylomicron remnants were suppressed by $>70 \%$ by an excess of unlabeled lipoproteins (not shown) or of anti-LDL receptor antibody (Fig. $1 a$ ). In contrast, the degrada-
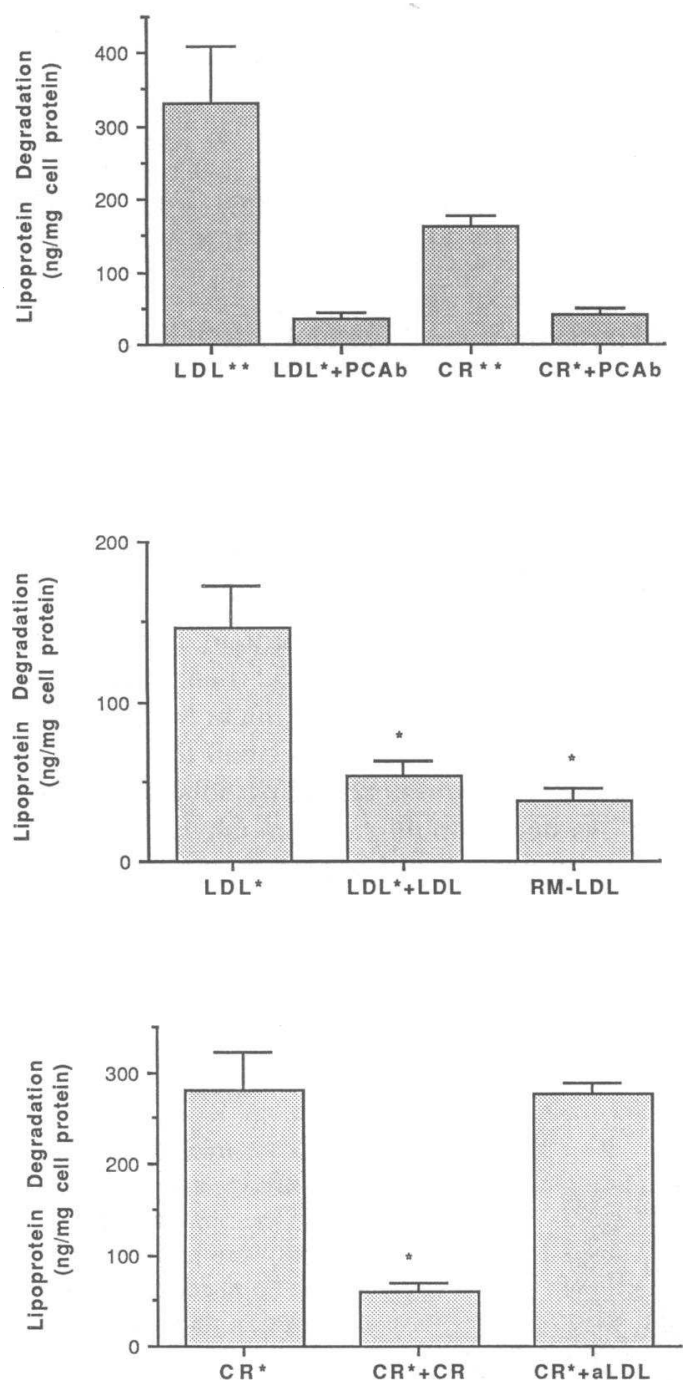

Figure 1. Degradation of lipoproteins by mouse macrophages. Mouse peritoneal macrophages were incubated with $10 \mu \mathrm{g} / \mathrm{ml}^{125} \mathrm{I}$-labeled LDL, reductively methylated (RM)-LDL or chylomicron remnants (CR) in the presence or absence of unlabeled lipoproteins $(500 \mu \mathrm{g} / \mathrm{ml})$ or anti-LDL receptor antibody $(500 \mu \mathrm{g} / \mathrm{ml})$ at $37^{\circ} \mathrm{C}$ for $4 \mathrm{~h}$. Degradation of ${ }^{125} \mathrm{I}$-labeled lipoproteins was determined as described under Methods. (A) Effect of polyclonal anti-LDL receptor antibodies (PCAb) on the degradation of labeled lipoprotein. LDL ${ }^{* *}, \mathrm{CR}^{* *}$ are the specific (total-nonspecific) degradation of labeled LDL or chylomicron remnants. $\mathrm{LDL}^{*}+\mathrm{PCAb}, \mathrm{CR}^{*}+\mathrm{PCAb}$ are the total degradation of LDL or chylomicron remnants in the presence of excess anti-LDL receptor antibody. $(B)$ Comparison of total degradation of ${ }^{125}$ I-LDL (LDL*) with that of ${ }^{125}$ I-RM-LDL (RM-LDL) and nonspecific degradation of ${ }^{125} \mathrm{I}-\mathrm{LDL}\left(\mathrm{LDL}^{*}+\mathrm{LDL}\right) ;(C)$ Comparison of total degradation of ${ }^{125} \mathrm{I}-\mathrm{CR}\left(\mathrm{CR}^{*}\right)$ in the presence of unlabeled $\mathrm{CR}\left(\mathrm{CR}^{*}\right.$ $+\mathrm{CR})$ or acetyl-LDL $\left(500 \mu \mathrm{g} / \mathrm{ml}, \mathrm{CR}^{*}+\mathrm{aLDL}\right) .{ }^{*} P<0.05$.

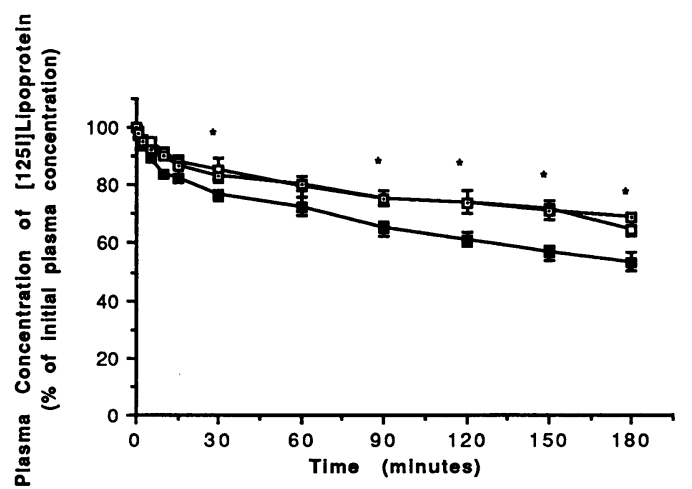

Figure 2. Effect of anti-LDL receptor antibody on the clearance of ${ }^{125}$ I-LDL from the blood of mice in vivo. Mice were injected intravenously with $0.1 \mathrm{ml}$ rabbit anti-LDL receptor $\mathrm{IgG}(0.5 \mathrm{mg})$ or saline. After $1 \mathrm{~h}$, they were injected intravenously with $20 \mu \mathrm{g}$ of ${ }^{125}$ I-human LDL or ${ }^{125}$ I-RM-LDL via the lateral tail vein, and blood samples (10 $\mu 1)$ taken for determination of radioactivity. Results are expressed as the amount of radiolabel remaining in the circulation as a percent of the initial plasma concentration which was calculated by extrapolating the amount of LDL or RM-LDL in the first two samples (i.e., 1 and $2.5 \mathrm{~min}$ ) back to time zero. Each point represents the mean \pm SE. ( $\square)$ LDL $(n=8)$; (口) LDL + anti-LDL receptor antibody $(n=4)$; (घ) RM-LDL $(n=8) .{ }^{*} P<0.05$.

tion of reductively methylated ${ }^{125} \mathrm{I}-\mathrm{LDL}(\mathrm{RM}-\mathrm{LDL})$ was significantly lower than ${ }^{125} \mathrm{I}-\mathrm{LDL}$ (Fig. $1 b$ ), indicating that the reductive methylation was effective in making the particles a poor ligand for the LDL receptor pathway. In addition, lipoproteins were screened for uptake by the acetyl LDL receptor. The uptake by these cells was low compared to acetyl LDL (not shown), was not blocked by an excess of unlabeled acetyl LDL (Fig. $1 c$ c), but was blocked by the anti-LDL receptor antibody (Fig. 1 a), demonstrating that they had not been converted to ligands for the acetyl LDL receptor by isolation, storage or iodination.

Effect of anti-LDL receptor antibody on the disappearance of ${ }^{125}$ I-LDL from plasma. The appropriate concentration to block LDL receptor activity in vivo was determined by comparing the plasma clearance of ${ }^{125} \mathrm{I}-\mathrm{LDL},{ }^{125} \mathrm{I}-\mathrm{RM}-\mathrm{LDL}$, and ${ }^{125}$ I-LDL plus anti-LDL receptor antibody. After the injection of ${ }^{125} \mathrm{I}-\mathrm{LDL}$ or ${ }^{125} \mathrm{I}-\mathrm{RM}-\mathrm{LDL}$, samples of blood were obtained and the amount of radioactivity determined. For these studies, the initial lipoprotein concentration was determined by extrapolating the first two time points back to time zero. From these data, it was calculated that $87 \%$ of the injected dose of LDL and RM-LDL reached the circulation. Both LDL and RM-LDL were removed slowly from the plasma. $3 \mathrm{~h}$ after injection, the plasma concentrations of ${ }^{125} \mathrm{I}-\mathrm{LDL}$ and ${ }^{125} \mathrm{I}-\mathrm{RM}$-LDL were $\sim 50$ and $70 \%$, respectively, of their initial concentrations (Fig. 2). Injection of $0.5 \mathrm{mg}$ anti-LDL receptor antibody $1 \mathrm{~h}$ before the injection of ${ }^{125} \mathrm{I}-\mathrm{LDL}$ reduced the disappearance of ${ }^{125} \mathrm{I}$ LDL to $30 \%$, a result virtually identical to that with RM-LDL. Nonimmune IgG did not affect the clearance of ${ }^{125}$ I-LDL or in later experiments of ${ }^{125} \mathrm{I}$-chylomicron remnants (data not shown); therefore in most experiments, a saline injection was used as a control. These results demonstrate that the antireceptor antibody blocks the interaction of human LDL with the high-affinity LDL receptors as effectively as did reductive methylation of the LDL. The effect of varying amounts of anti-LDL 


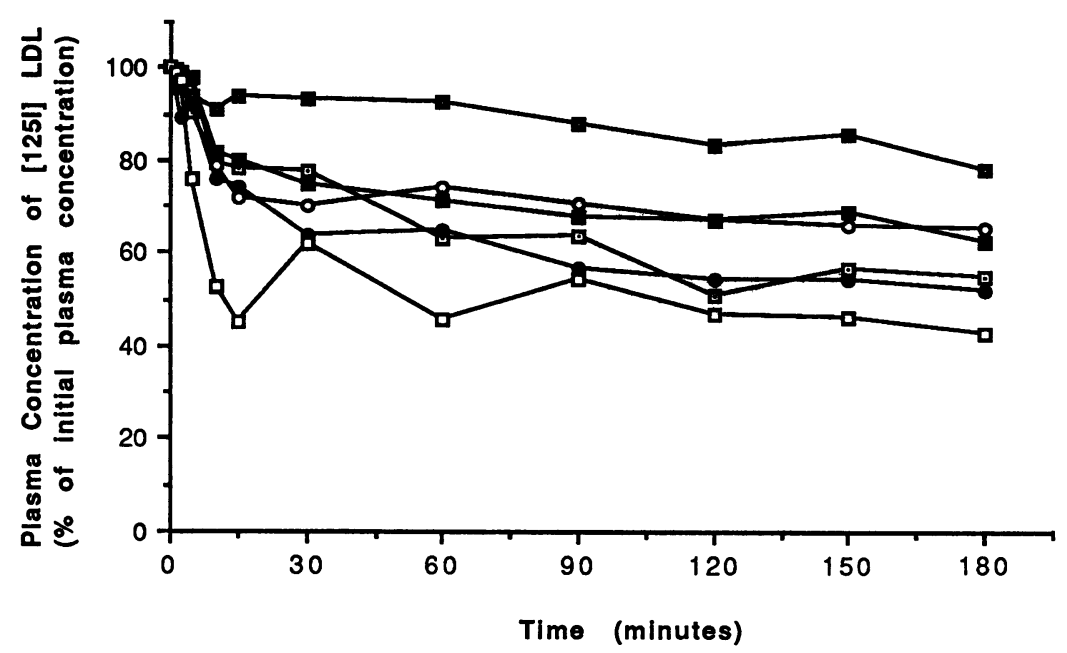

Figure 3. Effect of varying amounts of anti-LDL receptor antibody on the clearance of ${ }^{125}$ I-LDL from the blood of mice in vivo. The protocol was the same as in Fig. 2, except that the amount of rabbit antiLDL receptor IgG varied from 0.2 to $2.1 \mathrm{mg}$ per

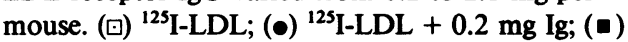
${ }^{125} \mathrm{I}-\mathrm{LDL}+0.5 \mathrm{mg} \mathrm{IgG}$; (0) ${ }^{125} \mathrm{I}-\mathrm{LDL}+1.0 \mathrm{mg} \mathrm{IgG}$; (a) ${ }^{125} \mathrm{I}-\mathrm{LDL}+1.3 \mathrm{mg} \mathrm{IgG}$; () ${ }^{125} \mathrm{I}-\mathrm{LDL}+2.1 \mathrm{mg}$ IgG. receptor antibody was also examined. The degree of inhibition was dependent upon the amount of antibody injected (Fig. 3). The maximum effect was obtained with $0.5 \mathrm{mg}$ per mouse. Injection of $>1.0 \mathrm{mg}$ actually resulted in reduced blockade, therefore, $0.5 \mathrm{mg}$ antibody was used in all subsequent experiments. The result that $\sim 40 \%$ of LDL uptake in the first $2 \mathrm{~h}$ in the mouse is dependent on the LDL receptor is somewhat lower than previous estimates with RM-LDL and autologous LDL in the rat (32) or rabbit (33).

Effect of anti-LDL receptor antibody on $L D L$ uptake by tissues. The specific tissue spaces of LDL were examined in several organs to assess the major tissue sites of LDL uptake in the mouse. After the final blood sample, the liver, adrenal gland, spleen, both kidneys and a piece of small intestine were removed and counted for radioactivity. The dry tissue weight was measured to reduce the variability due to the different amounts of organ moisture. This was also corrected for nonspecific trapping of lipoproteins by subtracting the tissue space determined for albumin. The differences between the ${ }^{125} \mathrm{I}$-labeled LDL and the ${ }^{125} \mathrm{I}$-albumin spaces for each tissue are re-

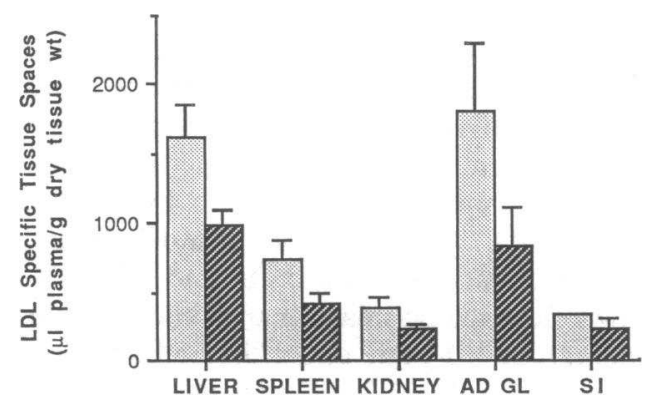

Figure 4. LDL-specific tissue spaces. ${ }^{125} \mathrm{I}-D L T-L D L ~(20 \mu \mathrm{g} / \mathrm{mouse})$ was injected $1 \mathrm{~h}$ after saline or $0.5 \mathrm{mg}$ anti-LDL receptor antibody and the animals sacrificed $3 \mathrm{~h}$ later. Tissues were removed, rinsed in saline, blotted dry, placed in an oven $\left(80^{\circ} \mathrm{C}\right)$ overnight, and then weighed. The radioactivity of the tissues was then measured. A similar experiment was conducted $3 \mathrm{~h}$ after injection of ${ }^{125} \mathrm{I}$-albumin. Tissue spaces were calculated as microliters plasma per gram dry tissue weight as described in Methods. The lipoprotein minus the albumin tissue space is the LDL-specific tissue space. Results are expressed as mean $\pm S E$ of values from three animals in each group. ( $\square$ ) CR; (घ) CR + anti-LDL receptor antibody. ferred to as "specific tissue spaces" (29). DLT-LDL was used in these studies to minimize the amount of degradation that might have occurred, subsequent to endocytosis $(34,35)$. The plasma clearance of DLT-LDL was identical to that of conventionally-labeled LDL (not shown).

Liver and adrenal gland were the most avid in accumulating both native LDL and DLT-LDL as compared to spleen, kidney, and small intestine (Fig. 4). By mass, the liver accounted for the uptake of $85 \%$ of the lipoprotein. It was somewhat surprising that the liver had a specific tissue space only slightly less than that of the adrenal. This might be due to the fact that, in the mouse, the adrenal is so small that we were unable to completely free it of surrounding adherent tissue, particularly fat. Consistent with this, immunoblots of liver and adrenal with equal amounts of applied protein confirmed that, on a protein basis, the adrenal gland is about twofold richer than the liver in LDL receptors (Fig. 5). After injection of antiLDL receptor antibodies, the specific tissue spaces of ${ }^{125}$ I-DLTLDL were reduced in both the liver and adrenal gland and to a lesser extent, in the spleen, kidney, and small intestine. Based

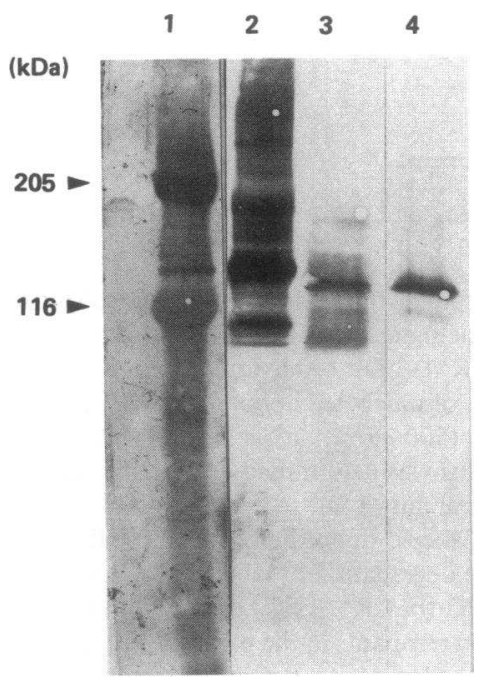

Figure 5. Immunoblots of mouse liver and adrenal gland membranes. Membranes were prepared from tissue homogenates by centrifugation and solubilized with CHAPS as described in Methods. Proteins were separated by electrophoresis on $6 \%$ polyacrylamide gels and then transferred to nitrocellulose. Strips were incubated with the anti-LDL receptor polyclonal rabbit serum followed by horseradish peroxidase conjugated goat anti-rabbit IgG. (Lane 1) Molecular weight standards (myosin, 205,000; $\beta$-galactosidase, 116,000); (lane 2) liver membranes from ethinyl estradiol-treated rats; (lane 3) liver membranes from normal mice; (lane 4) adrenal gland membranes from normal mice. 
on the data in Fig. 4, it was estimated that $45 \%$ of hepatic uptake and $55 \%$ of adrenal uptake of LDL was LDL receptordependent. These values are also lower than those obtained with RM-LDL in rat (32) and rabbit (33). Taken together, these results suggest that the anti-LDL receptor antibody blocks LDL uptake, but may result in an underestimation of the contribution of the LDL receptor-dependent pathway.

Effect of anti-LDL receptor antibody on the disappearance of ${ }^{125}$ I-chylomicron remnants from plasma. In agreement with other studies, ${ }^{125} \mathrm{I}$-chylomicron remnants were removed from the plasma at a very rapid rate (20). Due to the rapid disappearance, the initial plasma concentration was calculated based on the amount of chylomicron remnants injected, the estimated total blood volume and the percent loss of injected material, as determined in the LDL experiments. Using this to calculate the $T_{0}$ radioactivity, $\sim 33 \%$ of the injected particles were removed in $0.5 \mathrm{~min}$ and $48 \%$ in $2 \mathrm{~min}$ (Fig. 6). To examine the role of the LDL receptor in the removal of chylomicron remnants from the circulation, mice were first injected with the anti-LDL receptor antibody at a dose that was previously shown to maximally block LDL receptor-dependent clearance of LDL. At this concentration, the antibody reduced the very rapid (30 s) clearance to $25 \%$ and the 5 min clearance to $31 \%$ (Fig. 6). Based on this, at least $35 \%$ of the remnant disappearance could be attributed to the LDL receptor.

A significant portion of the radioactivity of the chylomicron remnants radiolabeled after isolation is located on proteins other than apoB. Although the time frame is very short, some of these might exchange in plasma with other lipoproteins; thus, it was possible that the radioactivity in plasma may represent labeled remnant apoproteins that had redistributed to other lipoproteins and not chylomicron remnants remaining in the circulation. To test this, plasma samples were analyzed after the injection of ${ }^{125}$ I-chylomicron remnants by agarose gel electrophoresis. If there was transfer of labeled apoproteins to other lipoproteins, their radioactivity would be associated with faster migrating lipoproteins that can easily be distinguished from chylomicron remnants which remain at the origin.
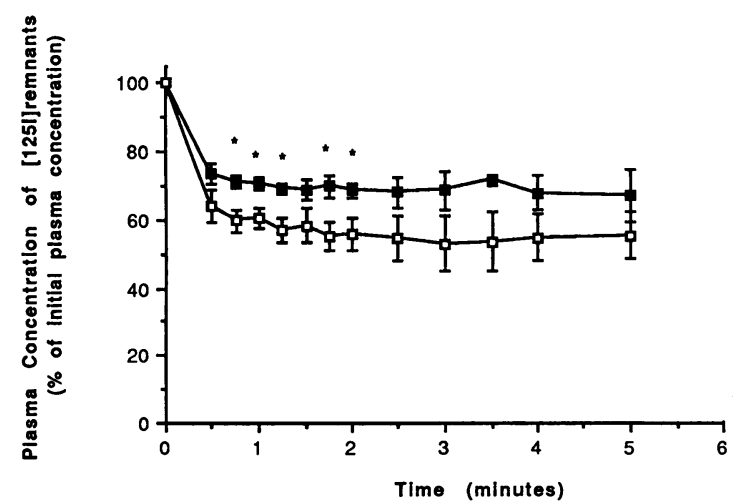

Figure 6. Effect of anti-LDL receptor antibody on the clearance of ${ }^{125}$ I-chylomicron remnants from the blood of mice in vivo. The protocol was the same as in Fig. 2 except that the animals were sacrificed $5 \mathrm{~min}$ after the injection of radiolabeled lipoproteins, and the concentration at time 0 was estimated from the actual amount injected corrected for loss, as determined in the LDL clearance experiments, divided by the estimated blood volume. Each point represents the mean \pm SE. ( $($ ) $\mathrm{CR}(n=5)$; ( $($ ) CR + anti-LDL receptor antibody ( $n$ $=6) .{ }^{*} P<0.05$.

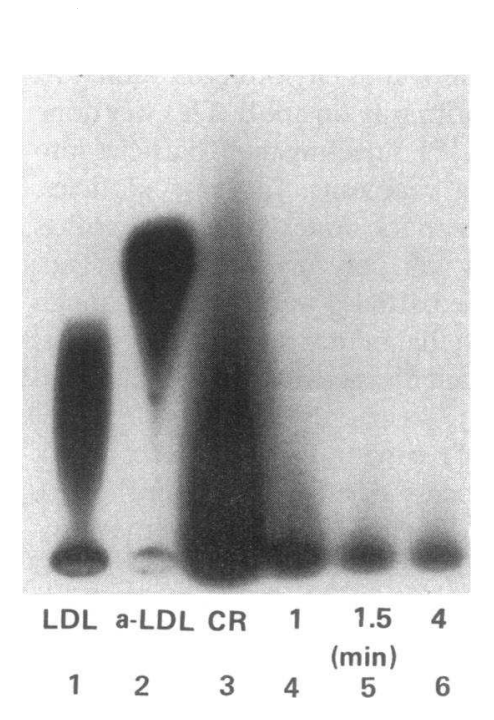

Figure 7. Agarose gel electrophoresis of plasma. To determine whether the radioactivity of ${ }^{125} \mathrm{I}$-chylomicron remnants redistributed to other lipoproteins, plasma samples $(30 \mu \mathrm{l})$ from mice after injection of ${ }^{125}$ I-chylomicron remnant were subject to agarose $(0.7 \%)$ gel electrophoresis. The gel was then exposed to x-ray film. (Lane 1) human LDL; (lane 2) acetylLDL; (lane 3) chylomicron remnants; (lane 4) plasma sample at $1 \mathrm{~min}$; (lane 5) plasma sample at $1.5 \mathrm{~min}$; (lane 6) plasma sample at 4 min.

Plasma samples were separated by agarose gel electrophoresis and autoradiograms prepared. The autoradiogram was purposely overexposed to reveal any radioactivity associated with nonchylomicron remnant lipoproteins. As expected, noninjected chylomicron remnants remained at the origin (Fig. 7, lane 3 ). In plasma samples collected up to $4 \mathrm{~min}$ after chylomicron remnant injection, there was no significant transfer of labeled apoprotein to other lipoprotein classes (Fig. 7, lanes 4-6). Also shown is the migration of labeled LDL (Fig. 7, lane 1) and acetyl-LDL (Fig. 7, lane 2) for comparison.

Because there is nonapoprotein protein on chylomicron remnants, particles containing a core label were also studied. Chylomicron remnants were labeled with ${ }^{3} \mathrm{H}$-cholesterol ester and their disappearance measured as above. Although the amount of radioactivity that could be injected limited the accuracy of the study, the results were similar to those with iodinated chylomicron remnants. The clearance of ${ }^{3} \mathrm{H}$-cholesterol ester-labeled chylomicron remnants was rapid with $\sim 80 \%$ removed after 5 min and the plasma clearance was suppressed by the anti-LDL receptor antibody (Fig. 8). To study remnant

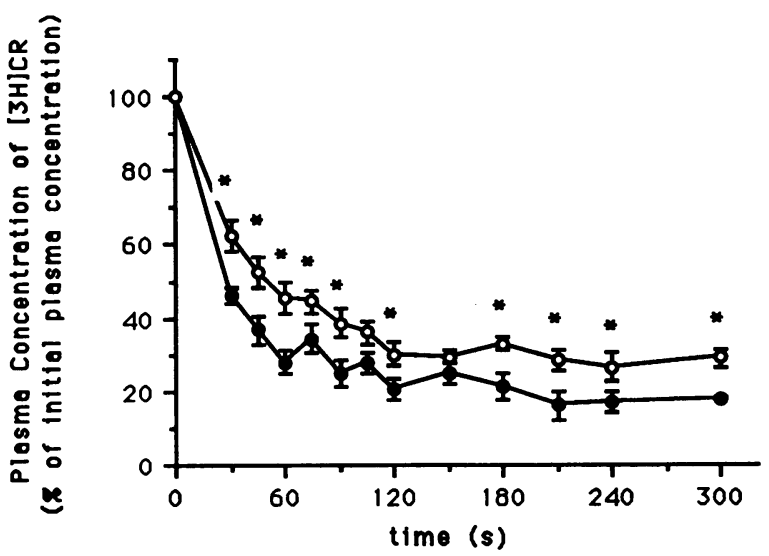

Figure 8. Effect of anti-LDL receptor antibody on the clearance of ${ }^{3} \mathrm{H}$-chylomicron remnants from the blood of mice in vivo. The protocol was the same as in Fig. 4 except that chylomicron remnants were labeled with ${ }^{3} \mathrm{H}$-cholesterol ester. Each point represents the mean \pm SE. $n=8$ for both remnants ( $\bullet$ ) and remnants + anti-LDL receptor antibody $(0) .{ }^{*} P<0.05$. 
removal over a longer time period without the possibility of exchange of radiolabel, the removal of chylomicron remnants were prepared with the label primarily on apoB. This was done by labeling chylomicrons with ${ }^{125} \mathrm{I}$, injecting these particles into eviscerated rats and isolating remnants. In these particles, $>80 \%$ of the radioactivity was on the nonexchangable apoB as assessed by radioautography of polyacrylamide gels (not shown). The clearance of these particles was similar, although somewhat more complete than that of in vitro labeled particles. After $1 \mathrm{~h}$, at least $25 \%$ of remnant disappearance was still due to the LDL receptor (Fig. 9).

The kinetics of clearance of remnants is somewhat complex and does not obey a single process kinetic model (not shown). With this preparation, the time for removal of $50 \%$ of the particles was $\sim 7 \mathrm{~min}$ in control and $\sim 21 \mathrm{~min}$ in antibody-treated mice, consistent with the LDL receptor playing a major role in their clearance. It should be noted, however, that even in the antibody-treated mice, remnant clearance was much more rapid than LDL clearance and by $1 \mathrm{~h}$, had proceeded to near completion in both groups. This suggests that the non-LDL receptor clearance pathway (6) has a higher affinity for remnants than for LDL, and the LDL receptor-independent path-
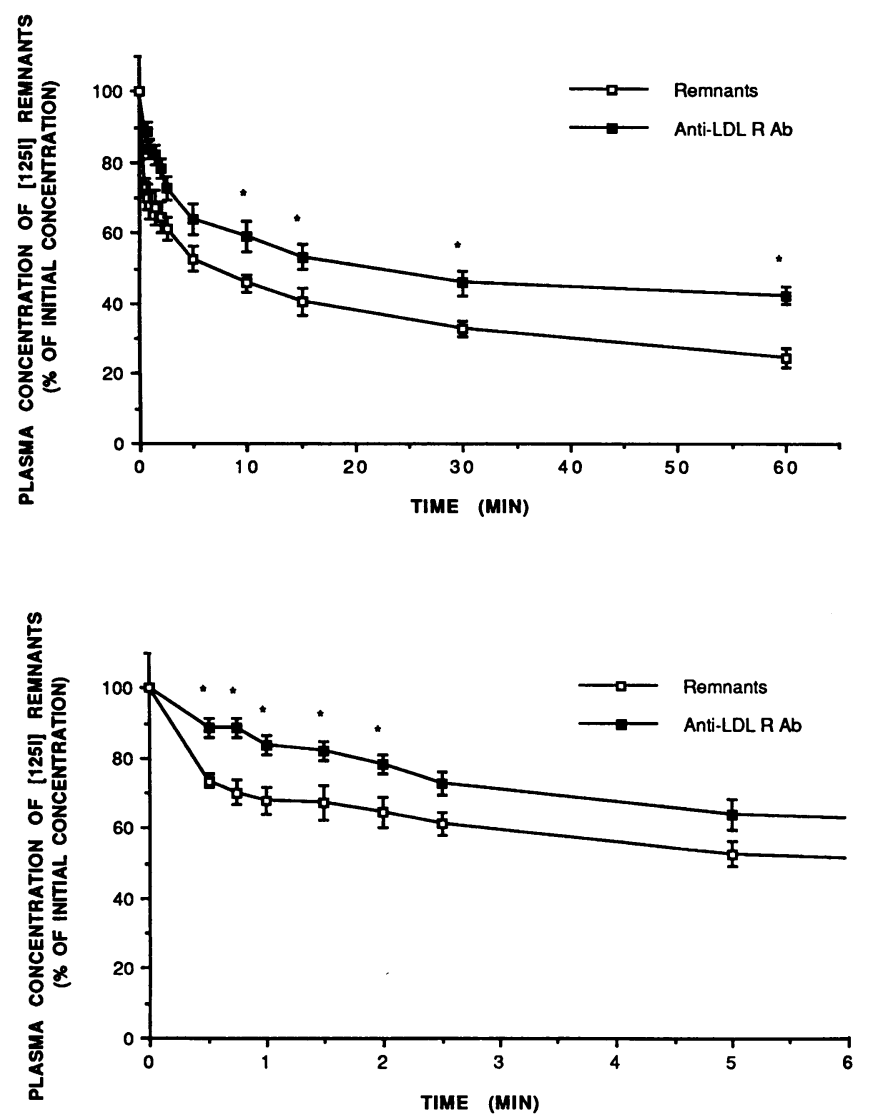

Figure 9. Effect of anti-LDL receptor antibody on clearance of ${ }^{125} \mathrm{I}$ chylomicron remnants from the blood of mice in vivo over the long term. To study remnant removal over a longer time period without the possibility of exchange of radioactivity, chylomicron remnants were prepared from ${ }^{125}$ I-chylomicrons. These particles have most of the radioactivity in apoprotein $B$. The protocol was the same as described in Fig. 2. (a) Entire time course; (b) first 6 min only. Each point represents the mean \pm SE. $n=4$ for remnants ( $\square$ ) and $n=6$ for remnants + anti-LDL receptor antibody $(\boldsymbol{\bullet}){ }^{*} P<0.05$.

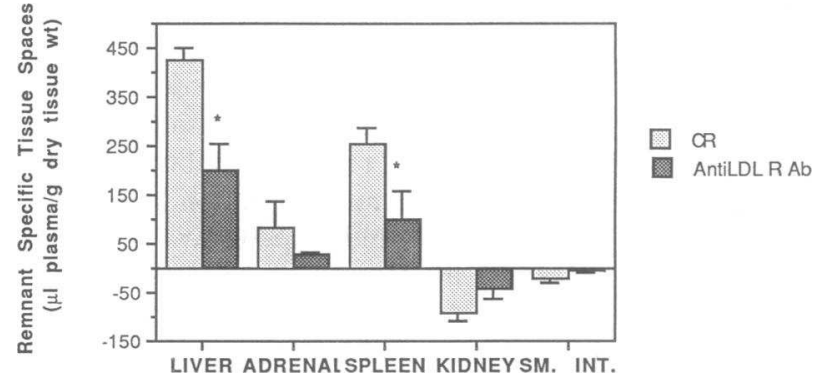

Figure 10. Effect of anti-LDL receptor antibody on chylomicron remnant specific tissue spaces. The same protocol was followed as described in the legend to Fig. 4, except that the animals were sacrificed $5 \mathrm{~min}$ after the injection of lipoprotein. Each point is the mean \pm SE. ( $\square$ ) CR $(n=3)$; ( $)$ CR + anti-LDL receptor antibody, $(n$ = 4). ${ }^{*} P<0.05$.

way can remove most of a bolus of remnants in a relatively short time.

Effect of anti-LDL receptor antibody on chylomicron remnant uptake by tissues. The liver, adrenal glands, spleen, kidney, and a piece of small intestine were removed and counted for radioactivity $5 \mathrm{~min}$ after the injection of chylomicron remnants. In contrast to LDL, the specific ${ }^{125}$ I-chylomicron remnant tissue space in the adrenal gland was significantly lower than that in the liver (Fig. 10). The injection of anti-LDL receptor antibody blocked the uptake of ${ }^{125} \mathrm{I}$-chylomicron remnants in the liver, adrenal gland, and spleen by at least $50 \%$ at the 5-min timepoint. This was similar to its effect on LDL uptake and suggests that the LDL receptor normally plays a major quantitative role in the rapid removal of chylomicron remnants in these tissues that is similar to that for LDL. However, in the 1-h clearance experiment of Fig. 9, the remnant space in the liver of antibody-treated animals was now only $\sim 25 \%$ less than in the control animals. This is consistent with the postulate that the non-LDL receptor pathway can compensate for the LDL receptor over a longer time period.

\section{Discussion}

These experiments establish for the first time that the LDL receptor plays a significant role in the removal of chylomicron remnants in the normal animal in vivo. This is not necessarily an unexpected conclusion because these particles contain a large amount of apoE and have been shown to bind and be taken up by the LDL receptor in a variety of cultured cells, including fibroblasts (36), macrophages (37), hepatomas (38), and isolated primary liver cells (10). However, a number of lines of evidence argued that the LDL receptor might be less important for remnant removal in vivo than this receptor is for LDL uptake. First, chylomicron remnants are removed from blood much more rapidly than LDL; second, the particles are removed by the liver almost exclusively (39), even though the adrenal gland has a higher density of LDL receptors (29); third, earlier studies from this laboratory (22) found normal uptake by the perfused liver of rats fed an atherogenic diet, a condition in which the LDL receptor is moderately downregulated; fourth, the Watanabe rabbit, which has a defective LDL receptor, removes chylomicron remnants rapidly (11) and fifth, humans with FH have not been reported to become unusually 
hypertriglyceridemic or hypercholesterolemic after a fat-containing meal.

To assess the role of the LDL receptor in chylomicron remnant removal, it was necessary to create an acute blockade of LDL receptor function because in any chronic model, such as a receptor-deficient rabbit, compensatory changes could occur, and the expansion of endogenous lipoprotein pools makes even simple kinetic studies difficult to interpret. The mouse was chosen because its small blood volume allowed us to achieve high antibody concentrations without the need for prohibitive amounts of antibody. Lipoprotein metabolism in the mouse has not been studied in the same detail as in several other species, such as rats, rabbits, and humans. However, the mouse has analogous lipoproteins and apoproteins to these species $(40,41)$, including apoAI, AII, B, C, and E, it has a receptor similar to the $\mathrm{LDL}$ receptor which recognizes both apoB and apoE (37), and it seems to be a reasonable model because no unusual metabolic features have been identified. The limitations of this study, caused by the small size of the animals, were that with ${ }^{3} \mathrm{H}$-cholesterol ester-containing particles, it was difficult to quantify the radioactivity in the later blood samples, and it was difficult to free the adrenal gland of all adherent tissue. The latter may account for the finding that LDL uptake per gram tissue dry weight was similar in liver and adrenal, whereas in most other species the adrenal is richer in LDL receptors. In fact, on immunoblots, when similar amounts of protein are applied, the adrenal gland appears to have a greater amount of LDL receptor than liver, although this difference may not be as great as in some other species. Nonetheless, because the same protocol was used with the two lipoprotein types in these studies, the relative difference between hepatic and adrenal tissue spaces with LDL and chylomicron remnants still remains.

In addition, the use of human LDL and rat chylomicron remnants represents a compromise; the use of homologous lipoproteins was not feasible because of the limited blood volume of the mouse. In previous cell culture studies from this laboratory (38), human LDL had only a slightly lower affinity for the rat LDL receptor than rat LDL; however, in in vivo studies by Dietschy and colleagues (32), there was a greater degree of LDL receptor-mediated uptake of rat lipoproteins in rat than of human lipoprotein in that species. This may be due to an ability of the rat particles to acquire apoE. Thus, our choice of lipoproteins may account for some of the quantitative differences between this study and those in the rat (32).

The antibody used has previously been thoroughly characterized $(9,10,27)$. It does not cross-react with the LRP or other proteins and inhibits uptake of both apoB- and apoE-containing lipoproteins in rat and murine cells. In general, on Western blots of noninduced liver, the liver receptor, its dimer, and a precursor are seen. Smaller bands are probably degradation products. All bands are induced by ethinyl estradiol treatment and react with a monoclonal anti-LDL receptor antibody (27). Interestingly, whereas it completely inhibits chylomicron remnant and $\beta$-VLDL uptake in fibroblast (37) and tumor lines (10), it is only $80-90 \%$ effective in macrophages (37) and hepatic cells (10). A dose-response experiment of LDL clearance with antibody showed an increase in blockade with up to 0.5 $\mathrm{mg}$ antibody injected and then, a paradoxical fall. This amount should provide an antibody concentration of $180 \mu \mathrm{g} / \mathrm{ml}$. Based on available information, this is roughly comparable on a protein basis to the apoB content of mouse blood. Because the antibody is a more potent competitor for LDL receptor binding than LDL, the antibody is probably present in excess of LDL, but perhaps not an adequate excess to completely compete for LDL uptake. Because apoE is a higher affinity ligand than apoB, the degree of blockade of apoE-mediated uptake may be less than that of apoB-mediated uptake. This may be somewhat mitigated by the fact that the endogenous apoE level is relatively low. Thus, because the blockade may not be complete, the contribution of the LDL receptor to the removal of the two types of particles estimated by this method should be taken as a minimum value. For LDL, the estimates that $35 \%$ of plasma disappearance, $45 \%$ of liver uptake, and $55 \%$ of adrenal uptake is due to the LDL receptor are lower than those that have been obtained in other species using labeled residualized homologous LDL and RM-LDL. The discrepancy between tissue uptake and plasma clearance suggests that either the estimate of initial concentration was inaccurate or there was some sequestration of particles. The latter possibility which could include some macrophage uptake seems quite plausible. Estimates for LDL receptor-mediated LDL removal from plasma in humans have been $67-80 \%$ (42); in the rabbit, $62-76 \%$ (33); and in the rat, $57-75 \%$ (32). Interestingly, in our study, RMLDL clearance gave the same estimate of receptor-mediated uptake as did antibody blockade. In general, adrenal has had the highest per gram receptor-mediated uptake and the liver, second $(29,32)$. Taken together, it is reasonable to conclude that the mouse is similar to other species with regard to LDL receptor-dependent uptake, although it may rely more heavily on the LDL receptor-independent pathway for lipoprotein removal, and that the antibody blockade method gives at worst, a modest underestimate of LDL receptor-dependent lipoprotein transport.

When studying chylomicron remnants, another problem presented itself in that remnant removal was so rapid it was not possible to estimate the initial concentration by extrapolating the initial time points to zero. To circumvent this, we examined uptake using the theoretical concentration (injected dose divided by estimated blood volume) as the initial concentration. When a comparison of the two approaches was made for LDL, it appeared that $\sim 13 \%$ of the injected material was lost between the test tube and the circulation. Because of the small volume injected, even the small amount remaining in the syringe and needle is a significant percentage. We then applied this correction to the initial theoretical remnant concentration. Because chylomicron remnants are larger and tend to aggregate and stick to surfaces more than LDL, this may be a modest underestimate and would result in an underestimate of LDL receptor-dependent clearance at the initial time point because such losses appear as components of LDL receptor-independent removal.

Taken together, all of these considerations suggest that our estimates of LDL receptor-mediated uptake of chylomicron remnants represent minimum values. Thus, the similarity of the percentage of remnant and LDL disappearance from the circulation that is mediated by the LDL receptor $(35 \%$ for LDL, 25-35\% for chylomicron remnants) and hepatic uptake (40\% for LDL and $53 \%$ for chylomicron remnants) suggests that in the normal animal, the LDL receptor is an important mediator of remnant removal and may even play a quantitatively comparable role to the one it plays for LDL. Strikingly, this is the case, even for the very rapid phase of remnant removal since a significant effect of anti-LDL receptor antibody 
was seen at the 30-s timepoint. Further, even though the liver had a higher "specific space" than the adrenal gland, this was due to an increase in the LDL receptor's contribution in proportion to the LDL receptor-independent contribution, suggesting that some factor other than LDL receptor density is responsible for the tissue distribution of uptake. This could be due simply to the size of the fenestrations in the space of Disse, allowing chylomicron remnants access to the hepatic LDL receptor and not to adrenal LDL receptors.

Although the LDL receptor appears to play a major role in remnant removal, the non-LDL receptor pathway(s) also plays a substantial role and can fully compensate for the LDL receptor when it is blocked by the anti-receptor antibody. Thus, even in the blockaded animal, the disappearance of remnants is much more rapid than that of other lipoproteins and is almost complete in $<1 \mathrm{~h}$. This can explain the data of Rubinsztein et al. (12) who did not find a marked impairment of remnant removal in patients with receptor-negative familial hypercholesterolemia. In that study, the total serum and chylomicron remnant response to oral retinyl palmitate was only modestly $(\sim 20 \%)$, and not significantly greater in FH than in normal patients. In contrast, patients who were homozygous for apo E-2 had markedly greater responses as would be expected if both removal mechanisms relied primarily on apo $E$ as the recognition signal. A role for the LDL receptor is further supported by the observation that remnant removal is accelerated by estrogen treatment which increases LDL receptor (43), but not LRP (unpublished observation) levels.

This, then, leaves open the question of the nature of the remnant removal mechanism when the LDL receptor is absent, defective, or downregulated. A simple hypothesis is that the recently-described LRP (13) provides the secondary pathway. Although it has been shown that this protein does bind apoE and apoB (14) and can initiate internalization (44), compared to the LDL receptor, at least in cell culture, it does so with a lower affinity and requires further enrichment of already apoE-rich particles with additional apoE $(45,46)$. Thus, under conditions where this was the only receptor operative, LDL clearances might be markedly delayed whereas, even though remnant clearance was slower than normal, it could still be quite rapid by comparison to normal LDL removal. This would also explain why the remnant removal curves are not more divergent at later time points. If remnant removal by LDL receptor has a $T_{1 / 2}$ of $30 \mathrm{~s}$ and non-LDL receptor of $90 \mathrm{~s}$ (threefold difference), in a perfect experiment, after $4.5 \mathrm{~min}$, $99 \%$ would be cleared by the LDL receptor and $88 \%$ by the non-LDL receptor pathway. Because there is some exchange and some slowly removed, or even resecreted radioactivity, this would account for the plateau and narrowing differences seen at the later timepoints. The disparity between the two particles would be further exaggerated if the ability to acquire additional apoE is required for binding because remnants are good substrates for apoE acquisition, whereas LDL does this poorly and in the case of humans, perhaps not at all. Further testing of this hypothesis will require complementary studies to these with an anti-LRP antibody or studies in LRP-deficient animals, if such can be found.

\section{Acknowledgments}

We wish to thank Dr. S. Azhar for providing DLT-LDL, Ms. Jean Chen for assistance with preparing the anti-LDL receptor antibody, and Ms. Jeanne Gill for assistance with the manuscript.
This work was supported by grants DK38318 and DK36659. Dr. Kirven and Dr. Choi are recipients of fellowships from the California Chapter of the American Heart Association. Preliminary reports of this research have been published in Clin. Res. (1990. 38:153a) and Arteriosclerosis (1990. 10:766).

\section{References}

1. Gofman, J. W., F. T. Lindgren, and H. Elliott. 1949. Ultracentrifugal studies of human serum. J. Biol. Chem. 179:973-981.

2. Brown, M. S., and J. L. Goldstein. 1979. Receptor-mediated endocytosis: insights from the lipoprotein receptor system. Proc. Natl. Acad. Sci. USA. 76:3330-3337.

3. Mahley, R. W., and T. L. Innerarity. 1977. Interaction of canine and swine lipoproteins with the low density lipoprotein receptor of fibroblasts as correlated with heparin/manganese precipitability. J. Biol. Chem. 252:3980-3986.

4. Goldstein, J. L., and M. S. Brown. 1977. The low-density lipoprotein pathway and its relation to atherosclerosis. Annu. Rev. Biochem. 46:897-930.

5. Attie, A. D., R. C. Pittman, Y. Watanabe, and D. Steinberg. 1981. Low density lipoprotein receptor deficiency in cultured hepatocytes of the WHHL rabbit. Further evidence of two pathways for catabolism of exogenous proteins. $J$. Biol. Chem. 256:9789-9792.

6. Mahley, R. W., D. Y. Hui, T. L. Innerarity, and U. Beisiegel. 1989. Chylomicron remnant metabolism. Role of hepatic lipoprotein receptors in mediating uptake. Arteriosclerosis. 9:I14-I18.

7. Spady, D. K., J. B. Meddings, and J. M. Dietschy. 1986. Kinetic constants for receptor-dependent and receptor-independent low density lipoprotein transport in the tissues of the rat and hamster. J. Clin. Invest. 77:1474-1481.

8. Shepherd, J., S. Bicker, A. R. Lorimer, and C. J. Packard. 1979. Receptormediated low density lipoprotein catabolism in man. J. Lipid. Res. 20:999-1006.

9. Cooper, A. D., R. Nutik, and J. Chen. 1987. Characterization of the estrogen-induced lipoprotein receptor of rat liver. J. Lipid Res. 28:59-68.

10. Nagata, Y., J. Chen, and A. D. Cooper. 1988. Role of low density lipoprotein receptor-dependent and -independent sites in binding and uptake of chylomicron remnants in rat liver. J. Biol. Chem. 263:15151-15158.

11. Kita, T., J. L. Goldstein, M. S. Brown, Y. Watanabe, C. A. Hornick, and R. J. Havel. 1982. Hepatic uptake of chylomicron remnants in WHHL rabbits: a mechanism genetically distinct from the low density lipoprotein receptor. Proc. Natl. Acad. Sci. USA. 79:3623-3627.

12. Rubinsztein, D. C., J. C. Cohen, G. M. Berger, D. R. van der Westhuyzen, G. A. Coetzee, and W. Gevers. 1990. Chylomicron remnant clearance from the plasma is normal in familial hypercholesterolemic homozygotes with defined receptor defects. J. Clin. Invest. 86:1306-1312.

13. Herz, J., U. Hamann, S. Rogne, O. Myklebost, H. Gausepohl, and K. K. Stanley. 1988. Surface location and high affinity for calcium of a $500 \mathrm{kDa}$ liver membrane protein closely related to the LDL receptor suggests a physiological role as a lipoprotein receptor. EMBO (Eur. Mol. Biol. Organ.) J. 7:4119-4127.

14. Kowal, R. C., H. Joachim, K. H. Weisgraber, R. W. Mahley, M. S. Brown, and J. L. Goldstein. 1990. Opposing effects of apolipoproteins $E$ and C on lipoprotein binding to low density lipoprotein receptor-related protein. J. Biol. Chem. 265:10771-10779.

15. Havel, R. J., H. A. Eder, and J. H. Bragdon. 1955. Distribution and chemical composition of ultracentrifugally separated lipoproteins in human serum. J. Clin. Invest. 34:1345-1353.

16. Pittman, R. C., T. E. Carew, C. K. Glass, S. R. Green, C. A. Taylor, Jr., and A. D. Attie. 1983. A radioiodinated, intracellularly trapped ligand for determining the sites of plasma protein degradation in vivo. Biochem. J. 212:791-800.

17. Basu, S. K., J. L. Goldstein, R. G. W. Anderson, and M. S. Brown. 1976. Degradation of cationized low density lipoprotein and regulation of cholesterol metabolism in homozygous familial hypercholesterolemia fibroblasts. Proc. Natl. Acad. Sci. USA. 73:3178-3182.

18. Weisgraber, K. H., T. L. Innerarity, and R. W. Mahley. 1978. Role of lysine residues of plasma lipoproteins in high affinity binding to cell surface receptors on human fibroblasts. J. Biol. Chem. 253:9053-9062.

19. Strobel, J. L., J. W. Baynes, and S. R. Thorpe. 1985. ${ }^{125}$ I-Glycoconjugate labels for identifying sites of protein catabolism in vivo: effect of structure and chemistry of coupling to protein on label entrapment in cells after protein degradation. Arch. Biochem. Biophys. 240:635-645.

20. Cooper, A. D. 1977. The metabolism of chylomicron remnants by isolated perfused rat liver. Biochim. Biophys. Acta. 488:464-474.

21. Redgrave, T. G., and G. Martin. 1977. Effects of chronic ethanol consumption on the catabolism of chylomicron triacylglycerol and cholesteryl ester in the rat. Atherosclerosis. 28:69-80.

22. Kris-Etherton, P. M., and A. D. Cooper. 1980. Studies on the etiology of the hyperlipemia in rats fed an atherogenic diet. J. Lipid Res. 21:435-442.

23. McFarlane, A. S. 1958. Efficient trace-labeling of proteins with iodine. Nature (Lond.). 182:53.

24. Fielding, C. J. 1978. Metabolism of cholesterol-rich chylomicrons. Mecha- 
nism of binding and uptake of cholesteryl esters by the vascular bed of the perfused rat heart. J. Clin. Invest. 62:141-151.

25. Van Zuiden, P. E. A., S. K. Erickson, and A. D. Cooper. 1983. The effect of lipoprotein composition on hepatic 3-hydroxy-3-methylglutaryl coenzyme A reductase activity and hepatic very low density lipoprotein secretion. J. Lipid Res. 24:418-428.

26. Lowry, O. H., N. J. Rosenbrough, A. L. Farr, and R. J. Randall. 1951. Protein measurement with the Folin phenol reagent. J. Biol. Chem. 193:265-275.

27. May, K., F. B. Kraemer, J. Chen, and A. D. Cooper. 1990. ELISA measurement of LDL receptors. J. Lipid Res. 31:1683-1691.

28. Garvey, J. S., N. E. Cremer, and D. H. Sussdorf. 1977. Bleeding of animals. In Methods in Immunology. 3rd ed. Benjamin/Cummings Publishing Co., Reading, MA. 20-35.

29. Spady, D. K., D. W. Bilheimer, and J. M. Dietschy. 1983. Rates of receptor-dependent and -independent low density lipoprotein uptake in the hamster. Proc. Natl. Acad. Sci. USA. 80:3499-3503.

30. Laemmli, U. K. 1970. Cleavage of structural proteins during the assembly of the head of bacteriophage T4. Nature (Lond.). 227:680-685.

31. Ellsworth, J. L., L. G. Fong, F. B. Kraemer, and A. D. Cooper. 1990. Differences in the processing of chylomicron remnants and $\beta$-VLDL by macrophages. J. Lipid Res. 31:1399-1411.

32. Spady, D. K., M. Huettinger, D. W. Bilheimer, and J. M. Dietschy, 1987. Role of receptor-independent low density lipoprotein transport in the maintenance of tissue cholesterol balance in the normal and WHHL rabbit. J. Lipid Res. 28:32-41.

33. Pittman, R. C., T. E. Carew, A. D. Attie, J. L. Witztum, Y. Watanabe, and D. Steinberg. 1982. Receptor-dependent and receptor-independent degradation of low density lipoproteins in normal rabbits and in receptor-deficient mutant rabbits. J. Biol. Chem. 257:7994-8000.

34. Koelz, H. R., B. C. Sherrill, S. D. Turley, and J. M. Dietschy. 1982. Correlation of low and high density lipoprotein binding in vivo with rates of lipoprotein degradation in the rat. A comparison of lipoproteins of rat and human origin. J. Biol. Chem. 257:8061-8072.

35. Pittman, R. C., A. D. Attie, T. E. Carew, and D. Steinberg. 1979. Tissue sites of degradation of low density lipoprotein: application of a method for determining the fate of plasma proteins. Proc. Natl. Acad. Sci. USA. 76:5345-5349.
36. Floren, C.-H., J. J. Albers, B. J. Kudchodkar, and E. L. Bierman. 1981. Receptor-dependent uptake of human chylomicron remnants by cultured skin fibroblasts. J. Biol. Chem. 256:425-433.

37. Ellsworth, J. L., F. B. Kraemer, and A. D. Cooper. 1987. Transport of $\beta$-very low density lipoproteins and chylomicron remnants by macrophages is mediated by the low density lipoprotein receptor pathway. J. Biol. Chem. 262:2316-2325.

38. Bernard, G. F., S. K. Erickson, and A. D. Cooper. 1984. Lipoprotein metabolism by rate hepatomas. J. Clin. Invest. 74:173-184.

39. Goodman, D. S. 1962. The metabolism of chylomicron cholesterol ester in the rat. J. Clin. Invest. 41:1886-1896.

40. Camus, M. C., M. J. Chapman, P. Forgez, and P. M. Laplaud. 1983. Distribution and characterization of the serum lipoproteins and apoproteins in the mouse, Mus musculus. J. Lipid Res. 24:1210-1228.

41. Forgez, P., M. J. Chapman, S. C. Rall, Jr., and M. C. Camus. 1984. The lipid transport system in the mouse, Mus musculus: isolation and characterization of apolipoproteins B, A-I, A-II and C-III. J. Lipid Res. 25:954-966.

42. Kesaniemi, Y. A., J. L. Witztum, and U. P. Steinbrecher. 1983. Receptormediated catabolism of low density lipoprotein in man. J. Clin. Invest. 71:950 959.

43. Everson, G. T., C. McKinley, and F. Kern, Jr. 1991. Mechanisms of gallstone formation in women. Effects of exogenous estrogen (Premarin) and dietary cholesterol on hepatic lipid metabolism. J. Clin. Invest. 87:237-246.

44. Herz, J., R. C. Kowal, Y. K. Ho, J. L. Goldstein, and M. S. Brown. 1990. Low density lipoprotein receptor-related protein mediates endocytosis of monoclonal antibodies in cultured cells and rabbit liver. J. Biol. Clin. 265:2135521362.

45. Kowal, R. C., J. Herz, J. L. Goldstein, V. Esser, and M. S. Brown. 1989 Low density lipoprotein receptor-related protein mediates uptake of cholesteryl esters derived from apoprotein E-enriched lipoproteins. Proc. Natl. Acad. Sci. USA. 86:5810-5814.

46. Weisgraber, K. H., R. W. Mahley, R. C. Kowal, J. Herz, J. L. Goldstein, and M. S. Brown. 1990. Apolipoprotein C-I modulates the interaction of apolipoprotein $E$ with $\beta$-migrating very low density lipoproteins $(\beta$-VLDL) and inhibits binding of $\beta$-VLDL to low density lipoprotein receptor-related protein. J. Biol. Chem. 265:22453-22459. 